\title{
The Effects of Oil Price Shocks on Transitional Dynamics of Turkish Business Cycle
}

\author{
Vasif ABIYYEV, Department of Economics, Faculty of Economics and Administrative Sciences, Aksaray \\ University, Turkey; e-mail: vabiyev@aksaray.edu.tr
}

Reşat CEYLAN, Department of Economics, Faculty of Economics and Administrative Sciences, Pamukkale University, Turkey; e-mail: rceylan@pau.edu.tr

Munise ILIKKAN ÖZGÜR, Department of Economics, Faculty of Economics and Administrative Sciences, AksarayUniversity, Turkey; e-mail: mozgur@aksaray.edu.tr

\section{Türk İş Çevrimlerinin Geçiş Dinamikleri Üzerine Petrol Fiyat Şoklarının Etkileri}

\begin{abstract}
In this study we investigated usefulness of oil price shocks in predicting switches between the growth phases of output in Turkey using monthly data for the period 1986-2014 by extending Markov Switching framework to include time-varying transition probabilities. We investigate the issue of whether the addition of various real oil price shocks to a univariate Markov Switching model for output can characterize the dynamics of business cycles better than the fixed transition probability version of Markov Switching model. The main results are summarized as follows. We find that although information about the lags of output growth and the information contained in transition probabilities combine to help identify which state of the economy has occurred in the TVTP model, oil price shocks are not the leading indicator of Turkish business cycle.
\end{abstract}
Keywords
Business Cycle, Markov Switching Regime, Oil Shocks, Leading Indicator.

JEL Classification Codes : $\quad$ E32, Q41, Q43.

\section{Öz}

Bu çalışmada, Türkiye'de çıktının büyüme süreçleri arasındaki kaymaların tahmininde petrol fiyatlarındaki şokların kullanışlılığı araştırılmaktadır. Analizde, 1986-2014 periyoduna ait aylık veriler kullanılmakta ve zaman değişimi geçiş olasılıklarını içeren çerçevede Markov rejim değişikliği modeli kullanılmaktadır. Bu analizde, çıktı için tekil Markov rejim değişikliği modeline çeşitli reel petrol fiyat şokları eklenerek, iş çevrimlerinin dinamiklerinin karakterize edilmesinde markov rejim değişikliği modelinin sabit geçiş olasılığ 1 versiyonunun kullanılıp kullanılamayacağı incelenmektedir. Çalışmadan elde edilen sonuçlar aşağıdaki gibidir: Her ne kadar TVTP modelinde çıktı büyümesinin gecikmeleri hakkında ve ekonomide oluşan durumun belirlenmesine yardım edecek geçiş olasılıkları hakkında içerilen bilgi olsa da, petrol fiyat şokları Türk İş Çevrimlerinin öncü göstergesi değildir. 


\section{Introduction}

There is a wide belief that oil price shocks have important effects on both economic activity and economic policy of all countries. These effects emerge from huge and sudden changes in oil prices. In an early seminal study, Hamilton (1983) finds a strong negative correlation between oil price changes and GNP growth using a multivariate vector autoregression (VAR) system.

Mork (1989) investigates asymmetric response of output to oil price changes by specifying real oil price increases and decreases and concludes that real oil price increases generates large negative effect on output while decrease in oil prices would not confer a positive effect on output. Hence, Mork (1989) proposes an asymmetric relation in which oil variable is given by the oil price change when oil prices go up but equal to zero when oil prices decline.

Hamilton (1996) argues that oil shocks affect the macroeconomy primarily by depressing demand for consumption and investment goods. Therefore, in order to measure the effect of oil price change on spending decisions of consumers and firms, it is appropriate to compare the current price of oil with where it has been over the previous year rather than during the previous quarter alone. Thus, Hamilton (1996) states that Mork (1989)'s proposal is not satisfactory and proposes a net real oil price increase variable that is defined as the percentage change in the current price of oil from the maximum value at some point during the previous year.

On the other hand, Lee, Ni and Ratti (1995) argue that an oil shock is likely to have greater impact on economic activity in an environment where oil prices have been stable than in an environment where oil price movements have been frequent and erratic because price changes in a volatile environment are likely to be soon reversed. A significant relationship between oil and economic activity implies that a certain oil price increase will cause a decrease in economic activity, while a price increase in a period of high volatility is less likely to cause it.

In order to investigate an empirical relationship between business cycle dynamics and oil price changes, one must address movements in business cycle. Hamilton (1989) has proposed a Markov switching (MS) model to investigate asymmetries in business cycle dynamics. In Hamilton (1989)'s analysis transition probabilities are fixed which means that the expected duration of a phase is constant. Filardo (1994) relaxes Hamilton (1989)'s fixed transition probabilities and allow them to depend on lagged various leading indicators for business cycles. Thus, Filardo (1994) uses time-varying transition probability (TVTP) MS model in which expected durations of phases vary across time. The TVTP MS model allows 
the transition probabilities to rise just before a contraction or an expansion begins, whereas a fixed transition probability (FTP) MS model doesn't.

Our study investigates the usefulness of oil price shocks in predicting switches between the growth phases of output in Turkey using monthly data for the period 1986-2014. Using MS framework, our model maintains that the behavior of output is different during expansions and contractions and can be characterized by shifts between positive and negative growth state. We investigate whether the TVTP MS model that using real oil price changes as a leading indicator for output can improve the fit of the data over the FTP model. We find that although information about the lags of output growth and the information contained in transition probabilities combine to help identify which state of the economy has occurred in the TVTP model, oil price shocks are not the best leading indicator of Turkish business cycle.

The paper is structured as follows. Section 2 discusses the methodology, section 3 presents data and discusses the empirical results, and Section 4 concludes the study.

\section{Methodology}

Following Hamilton, we consider the following MS model for real output.

$$
\Delta y_{t}-\mu\left(s_{t}\right)=\sum_{i=1}^{p} \alpha_{i}\left(\Delta y_{t-i}-\mu\left(s_{t-i}\right)\right)+\varepsilon_{t}, \quad \varepsilon_{t} \sim \mathrm{N}\left(0, \sigma^{2}\right)
$$

where $\Delta y_{t}$ is the growth rate of the real GDP, $\mu$ is the mean of the process and depends on the discrete random variable $s_{t}$ that reflects unobserved state of the economy. This dependence implies that different regimes are associated with different conditional distributions of the growth rate of the GDP. In case of two regimes, the unobserved states represent "expansionary" and "recessionary" states in the GDP. Hamilton (1989) assumes that the transition between the two unobserved states is governed by a first-order Markov process and the transition probabilities between states are constant: 


$$
\begin{aligned}
& P\left[s_{t}=1 \mid s_{t-1}=1\right]=p_{11} \\
& P\left[s_{t}=0 \mid s_{t-1}=1\right]=1-p_{11} \\
& P\left[s_{t}=0 \mid s_{t-1}=0\right]=p_{22} \\
& P\left[s_{t}=1 \mid s_{t-1}=0\right]=1-p_{22}
\end{aligned}
$$

There can be asymmetry in the persistence of regimes. In case of two-regime GDP growth model (1), if $\mu_{1}$ is negative and large in absolute value and $p_{11}$ is small, downward movements in the GDP are short but sharp. On the other hand, if $\mu_{2}$ is positive and small and $p_{22}$ is large, upward movements in the GDP are gradual and weak. Another possibility is the long swings hypothesis proposed by Engel and Hamilton (1990): if $\mu_{1}$ and $\mu_{2}$ are opposite in sign and that the values of both $p_{11}$ and $p_{22}$ are large, there are long swings in the business cycle.

Filardo (1994) and Diebold, Lee and Weinbach (1994) extended Hamilton (1989)'s two-state FTP MS model to allow for time-varying transition probabilities. In our model, the transition probabilities are allowed to depend on lagged oil price increases. The logistic functional form for the time-varying transition probabilities ensures that the transition probabilities lie in the open interval $(0,1)$. The parameterization of the logistic functional form of the transition probabilities is

$$
p_{11}\left(o i l_{t}\right)=\frac{\exp \left(\gamma_{10}+\sum_{i=1}^{I} \gamma_{1 i} o i l_{t-i}\right)}{1+\exp \left(\gamma_{10}+\sum_{i=1}^{I} \gamma_{1 i} o i l_{t-i}\right)}
$$

and

$$
p_{22}\left(o i l_{t}\right)=\frac{\exp \left(\gamma_{20}+\sum_{i=1}^{I} \gamma_{2 i} o i l_{t-i}\right)}{1+\exp \left(\gamma_{20}+\sum_{i=1}^{I} \gamma_{2 i} o i l_{t-i}\right)}
$$


where oil $_{t}$ represents one of four alternative specifications of oil price shocks (namely, $\Delta$ roil $_{t}, \Delta$ roil $\left._{t}^{+}, \mathrm{NOPI}_{t}, S O P I_{t}\right)$. In this specification, the FTP model corresponds to the restriction $\gamma_{1 i}=\gamma_{2 i}=0$ for $i \neq 0$. The FTP restriction can be tested against TVTP model by applying likelihood-ratio test. The Akaike information criterion (AIC) and the Schwartz information criterion (SIC) are employed to choose the appropriate order of the lags of the oil $_{t}$ variable in the TVTP. The type of "news" contained in the oil $l_{t}$ variables can be inferred from the movements in $p_{11}\left(\right.$ oil $\left._{t}\right)$ and $p_{22}\left(\right.$ oil $\left._{t}\right)$. As described by Filardo (1994), if $p_{11}\left(o_{t}\right)$ increases and $p_{22}\left(o_{i} l_{t}\right)$ decreases when oil increases, both the transition probability from the low-growth-rate state to the low-growth-rate state rises and the transition probability from the high-growth-rate state to the low-growth-rate state also rises (i.e., $1-p_{22}\left(o i l_{t}\right)$ increases). In other words, regardless of the economy's state at time $t$, the probability of being in the low-growth-rate-state at time $t+1$ increases. In this sense, the news in oil $_{t}$ is bad news. In the univariate specification for $p_{11}\left(o i l_{t}\right)$ and $p_{22}\left(o i l_{t}\right)$, the bad-news content of oil $_{t}$ is measured by positive $\gamma_{1 i}$ and negative $\gamma_{2 i}$.

\section{Data and Empirical Results}

We use monthly data of seasonally adjusted total industrial production index (IP) for Turkey and real oil price for the period 1986:1-2014:9. Real oil price $\left(\right.$ roil $\left._{t}\right)$ is obtained by multiplying the nominal oil price expressed in U.S. Dollars by the nominal exchange rate and deflating it by consumer price index (CPI). Thus, the real oil price reflects exchange rate fluctuations and inflation variations as well. The data for the IP and the oil price are obtained from the IFS. Both data are expressed in logarithmic first differences. The logarithmic first difference of IP is referred to as the output growth rate.

In order to account for the asymmetric effects of oil shocks, we introduce four different definitions of oil shocks. The first is the logarithmic first differences of the real oil price, i.e. $\Delta \operatorname{roil}_{t}, \mathrm{t}=1, \ldots, \mathrm{T}$.

$$
\Delta \text { roil }_{t}=\ln \text { roil }_{t}-\ln \text { roil }_{t-1}
$$

The second variable is defined as the positive change in the logarithm of the real oil price suggested by Mork 1989. 


$$
\Delta \operatorname{roil}_{t}^{+}=\left\{\begin{array}{l}
\Delta \text { roil }_{t}, \quad \text { if } \quad \Delta \text { roil }_{t}>0 \\
0, \quad \text { if } \quad \Delta \text { roil }_{t} \leq 0
\end{array}\right.
$$

The third definition is the net oil price increases $\left(N O P I_{t}\right)$ suggested by Hamilton (1996). The NOPI ${ }_{t}$ is defined as the positive percentage change in the current price of oil from the maximum value at some point during the previous year:

$$
\text { NOPI }_{t}=\left\{\begin{array}{l}
\ln \text { roil }_{t}-\max \left(\ln \text { roil }_{t-1}, \ldots, \ln \text { roil }_{t-12}\right), \quad \text { if } \quad \ln \text { roil }_{t}>\max \left(\ln \text { roil }_{t-1}, \ldots, \ln \text { roil }_{t-12}\right) \\
0, \quad \text { otherwise }
\end{array}\right.
$$

Following Lee, Ni and Ratti (1995), the fourth oil shock variable is aimed at capturing the volatility in the oil price market. Lee, Ni and Ratti (1995) normalize the oil price changes with their GARCH volatility. Following them, the resulting normalized or standardized oil price increases $\left(S O P I_{t}\right.$ ) are calculated according to the following model ${ }^{1}$ :

$$
\begin{aligned}
& \Delta \text { roil }_{t}=\alpha_{0}+\sum_{i=1}^{p} \alpha_{i} \Delta \text { roil }_{t-1}+\varepsilon_{t}, \quad \varepsilon_{t} \sim \mathrm{N}\left(0, \mathrm{~h}_{\mathrm{t}}\right) \\
& h_{t}=\gamma_{0}+\gamma_{1} \varepsilon_{t-1}^{2}+\gamma_{2} h_{t-1}
\end{aligned}
$$

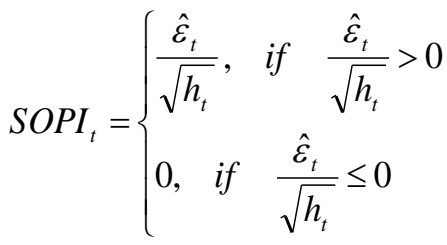

1 We estimated AR(8)-GARCH(1,1) model with $t$-distributed innovations. AIC and SBC are used to determine the optimal number of lags for oil price change $(p=8)$. 
section.

Figure 1 presents alternative measures of oil price shocks discussed so far in this

\section{Figure: 1}

\section{Alternative Measures of Oil Price Shocks}
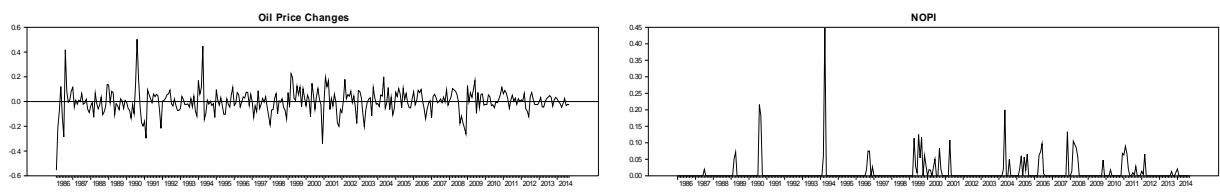

Positive Oil Price Changes

sopI
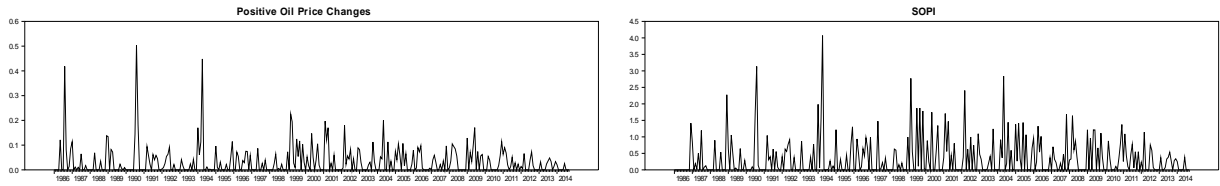

Following, Filardo (1994) and Raymond and Rich (1997), we investigate whether oil price shock information contained in transition probabilities in TVTP MS model can characterize the dynamics of business cycle better than the FTP version. 
Table: 1

FTP and TVTP estimates of MS Model for Output

\begin{tabular}{|c|c|c|c|c|c|}
\hline Parameter & Univariate FTP Model & $\begin{array}{l}\text { TVTP Model } \\
\left(\Delta \text { roil }_{t}\right)\end{array}$ & $\begin{array}{c}\text { TVTP Model } \\
\left(\Delta \text { roil }_{t}^{+}\right)\end{array}$ & $\begin{array}{l}\text { TVTP Model } \\
\left(N O P I_{t}\right)\end{array}$ & $\begin{array}{l}\text { TVTP Model } \\
\left(\mathrm{SOPI}_{t}\right)\end{array}$ \\
\hline$\mu_{1}$ & $\begin{array}{c}-0.0476^{* * *} \\
(0.0105)\end{array}$ & $\begin{array}{c}-0.0446^{* * * *} \\
(0.0105)\end{array}$ & $\begin{array}{l}-0.0566^{* * *} \\
(0.0111)\end{array}$ & $\begin{array}{l}-0.0367^{* * * *} \\
(0.0098)\end{array}$ & $\begin{array}{l}-0.0581^{* * * *} \\
(0.0122)\end{array}$ \\
\hline$\mu_{2}$ & $\begin{array}{l}0.0062^{* * *} \\
(0.0014)\end{array}$ & $\begin{array}{l}0.0058^{* * * *} \\
(0.0012)\end{array}$ & $\begin{array}{l}0.0067^{* * * *} \\
(0.0016)\end{array}$ & $\begin{array}{l}0.0064^{* * * *} \\
(0.0013)\end{array}$ & $\begin{array}{l}0.0066^{* * * *} \\
(0.0014)\end{array}$ \\
\hline$\alpha_{1}$ & $\begin{array}{l}-0.8139^{* * * *} \\
(0.0544)\end{array}$ & $\begin{array}{l}-0.7996^{* * * *} \\
(0.0520)\end{array}$ & $\begin{array}{l}-0.8283^{* * *} \\
(0.0605)\end{array}$ & $\begin{array}{l}-0.8146^{* * * *} \\
(0.0532)\end{array}$ & $\begin{array}{l}-0.8263^{* * * *} \\
(0.0577)\end{array}$ \\
\hline$\alpha_{2}$ & $\begin{array}{l}-0.2896^{* * *} \\
(0.0618)\end{array}$ & $\begin{array}{l}-0.2834^{* * * *} \\
(0.0595)\end{array}$ & $\begin{array}{l}-0.2948^{* * *} \\
(0.0697) \\
\end{array}$ & $\begin{array}{l}-0.2949^{* * *} \\
(0.0587) \\
\end{array}$ & $\begin{array}{l}-0.2968^{* * *} \\
(0.0661)\end{array}$ \\
\hline$\sigma_{\varepsilon}$ & $\begin{array}{l}0.00141^{\text {**** }} \\
(0.00012)\end{array}$ & $\begin{array}{l}0.00146^{* * *} \\
(0.00012)\end{array}$ & $\begin{array}{l}0.00136^{* * *} \\
(0.00013)\end{array}$ & $\begin{array}{l}0.00143^{* * *} \\
(0.00012)\end{array}$ & $\begin{array}{l}0.00137^{* * *} \\
(0.00014)\end{array}$ \\
\hline$p_{11}$ & $\begin{array}{l}0.508^{* * *} \\
(0.2312)\end{array}$ & & & & \\
\hline$p_{22}$ & $\begin{array}{l}0.976^{* *} \\
(0.0175)\end{array}$ & & & & \\
\hline$\gamma_{10}$ & & $\begin{array}{l}0.5772 \\
(0.7228)\end{array}$ & $\begin{array}{l}-1.8883 \\
(1.2194)\end{array}$ & $\begin{array}{l}1.0285 \\
(0.8868)\end{array}$ & $\begin{array}{l}-2.7068^{*} \\
(1.6573)\end{array}$ \\
\hline$\gamma_{11}$ & & $\begin{array}{l}3.3202 \\
(5.2901)\end{array}$ & $\begin{array}{l}16.5389 \\
(16.7473)\end{array}$ & $\begin{array}{l}-13,6936 \\
(45.8916)\end{array}$ & $\begin{array}{l}3.5125 \\
(3.5128)\end{array}$ \\
\hline$\gamma_{20}$ & & $\begin{array}{l}5.2024^{* * * *} \\
(1.5362)\end{array}$ & $\begin{array}{l}3.2271^{* * *} \\
(0.7569)\end{array}$ & $\begin{array}{l}4.2773^{* * * *} \\
(0.8910)\end{array}$ & $\begin{array}{l}2.9903^{* * * *} \\
(0.6592)\end{array}$ \\
\hline$\gamma_{21}$ & & $\begin{array}{l}17.0932^{*} \\
(8.8610)\end{array}$ & $\begin{array}{l}3.3847 \\
(10.2035)\end{array}$ & $\begin{array}{l}-19.1350^{* *} \\
(8.8376)\end{array}$ & $\begin{array}{l}2.3007 \\
(3.1684)\end{array}$ \\
\hline $\log \mathrm{L}$ & 611.1359 & 613.9234 & 612.1546 & 612.727 & 612.4241 \\
\hline AIC & -3.53296 & -3.53756 & -3.5272 & -3.5306 & -3.5288 \\
\hline SIC & -3.45447 & -3.43665 & -3.4263 & -3.4297 & -3.4279 \\
\hline
\end{tabular}

Second column in Table 1 reports the estimation results of Hamilton (1989)'s FTP MS model. The point estimates of state-dependent means, $\mu_{1}$ and $\mu_{2}$, are statistically significant. This means that two distinct growth rate phases characterize monthly industrial production. Each phase can be labelled as recessionary and expansionary states of the economy. Because the point estimate of mean growth rate in state 1 is negative, this state represents low-growth state of the economy. Similarly, positive point estimate of mean growth rate in state 2 represents high-growth state of the economy. If we compare the contraction regime with the expansion regime, the expansion regime is slow and highly persistent: average growth rate for expansion regime is $0.62 \%$ per month and the average duration of expansion regime is $\left(1-p_{22}\right)^{-1}=(1-0.976)^{-1}=41.7$ months. However, contraction regime is sharp and relatively short: average growth rate for contraction regime is $-4,76 \%$ per month and the average duration of contraction regime is 
$\left(1-p_{11}\right)^{-1}=(1-0.508)^{-1}=2$ months. Figure 2 plots smoothed probability of a recessionary state in the univariate model. Shaded areas in Figure 2 are recession periods of the economy. These periods corresponds to the crisis periods in Turkey, namely 1990-1991 oil crisis due to Iraq's invasion of Kuwait, 1994 exchange rate crisis, 1998 Russian stock market crisis, recessionary effect of August 1999 earthquake on the economy, 2000-2001 financial sector crisis and 2008-2009 global financial crisis. However, the recessionary effects of 1998 Russian stock market crisis and August 1999 earthquake on the economy remain less than $50 \%{ }^{2}$. The recessionary periods in Figure 2 doesn't perfectly approximate the dates of recessionary periods reported by the OECD (see Table 2).

Figure: 2

\section{Smoothed Probability of Economy Being in Contraction in the Univariate FTP Model}

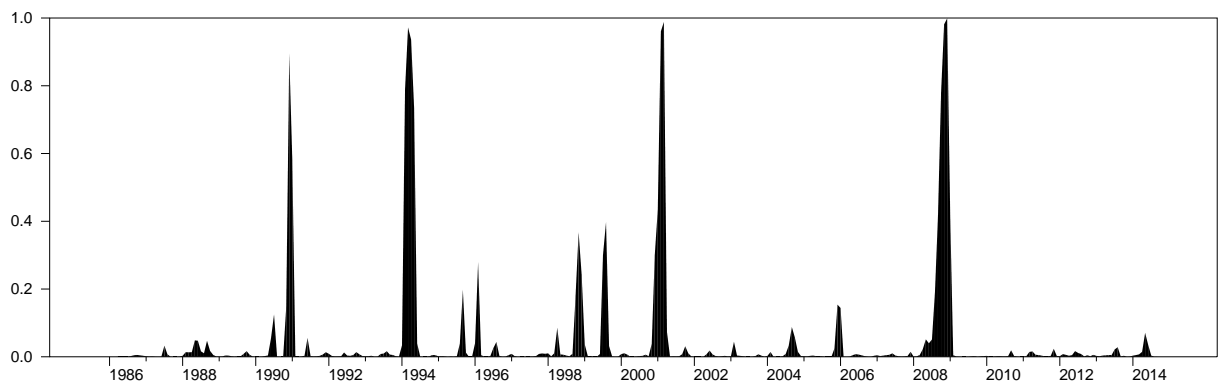

In the TVTP model, if we associate with oil price increases, which come in the form of "bad" news, then we would expect the coefficient estimates of $\gamma_{11}$ to be positive and the coefficient estimates of $\gamma_{21}$ to be negative so that the probability of being in the low-growth state in a subsequent period increases regardless of the current state of the economy.

Columns (3)-(6) in Table 1 shows the estimation results of TVTP models with various oil price shocks. The coefficient estimates of $\gamma_{21}$ in TVTP models with $\Delta$ roil $l_{t}$, $\Delta$ roil $_{t}^{+}$and $\mathrm{SOPI}_{t}$ variables have positive signs which mean that transition probabilities

2 We assign the $t$-th observation of the IP to the recessionary regime if $\operatorname{Pr}\left(s_{t}=1 \mid \Delta y_{t}>0.50\right)$. 
$p_{11}$ and $p_{22}$ move in the same direction when the oil price increases. So the TVTP coefficients don't represent "bad" news for these specifications. On the other hand, bad news is best illustrated with $N O P I_{t}$ information. Although $\gamma_{11}$ has the same sign with $\gamma_{21}$ in the TVTP model with $N O P I_{t}$ specification, $\gamma_{11}$ is statistically insignificant. According to this specification, a rise in the net oil price shock in the previous period comes in the form of "bad" news in the current period which results in low $p_{22}$ level. This result indicates that although net oil price increases don't significantly cause $p_{11}$ to rise in the current period, it helps to identify business cycle turning points in Turkish economy.

Table: 2

\section{Business Cycle Dates For Turkey ${ }^{3}$}

\begin{tabular}{|l|l|l|l|l|l|l|}
\hline $\begin{array}{l}\text { Peak } \\
\text { Trough }\end{array}$ & 1987M11 & 1993M8 & 1998M1 & 2000M8 & 2006M7 & 2011M5 \\
\hline
\end{tabular}

Figure: 3

Smoothed Probability of Economy Being in Contraction in the TVTP Model with the NOPI

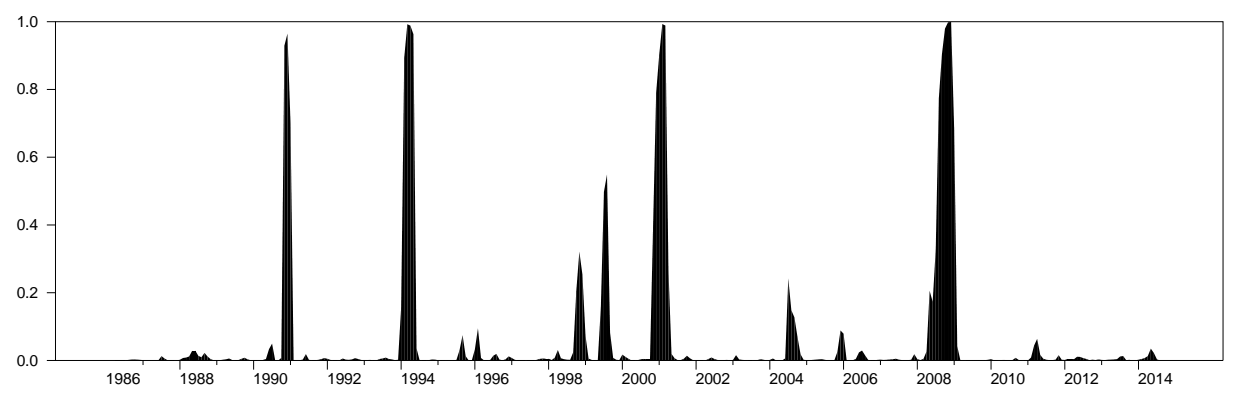

Figure 3 plots smoothed probability result of the contractionary phases of economy for the TVTP model with $N_{\text {OPI }}$ information. As seen from the Figure 3, although

3 The dates are obtained from the webpage of the OECD that publishes the OECD Composite Leading Indicators: Turning Points of Reference Series and Component Series, <http://www.oecd.org/std/leadingindicators/oecdcompositeleadingindicatorsreferenceturningpointsandcomponentseries.htm >, 22.09.2014. 
$N O P I_{t}$ information in TVTP model characterizes the dynamics of business cycle better than the FTP model, it reveals limited information about the state of the economy as seen from the Table 2. We can draw two conclusions from our analysis. First, time variation in transition probabilities is important in accounting for the evaluation of Turkish business cycle dynamics. Second, oil price shocks or more specifically net oil price increases are not the leading indicator of Turkish business cycle.

\section{Conclusion}

In this study we investigated usefulness of oil price shocks in predicting switches between the growth phases of output in Turkey using monthly data for the period 1986-2014 by extending MS framework to include time-varying transition probabilities. Using MS framework, our model maintains that the behavior of output is different during expansions and contractions and can be characterized by shifts between positive and negative growth state. We investigate the issue of whether the addition of various real oil price shocks to a univariate MS model for output can characterize the dynamics of business cycles better than the FTP version of MS model. The main results are summarized as follows.

The coefficient estimates of TVTP models reveals that various oil price shocks don't represent leading indicators for business cycle turning points. Besides, although $N P_{t}$ information in TVTP model characterizes the dynamics of business cycle better than the FTP model, it reveals limited information about the state of the economy. As a result, we can draw two conclusions from our analysis. First, time variation in transition probabilities is important in accounting for the evaluation of Turkish business cycle dynamics. Second, oil price shocks or more specifically net oil price increases are not a leading indicator of Turkish business cycle. In this respect, we recommend that future studies tend to investigate a detailed analysis of the business cycle by incorporating other fundamental factors (such as exchange rate, import price index, unit cost of import, inflation etc.) in the univariate MS model.

\section{References}

Diebold, F.X. \& J-H. Lee \& G.C. Weinbach (1994), "Regime Switching with Time-Varying Probabilities", in: C.P. Hargreaves (Ed.), Nonstationary Time Series Analysis and Cointegration, Oxford: Oxford University Press, 283-302.

Engel, C. \& J.D. Hamilton (1990), "Long swings in the dollar: Are they in the data and do markets know it?", American Economic Review, 80, 689-713.

Filardo, A.J. (1994), "Business-Cycle Phases and Their Transitional Dynamics”, Journal of Business \& Economic Statistics, 12(3), 299-308. 
Hamilton, J.D. (1983), “Oil and the Macroeconomy since World War II”, Journal of Political Economy, 91(2), 228-248.

Hamilton, J.D. (1989), "A new approach to the economic analysis of non-stationary time series and the business cycle", Econometrica, 57, 357-384.

Hamilton, J.D. (1996), “This is What Happened to the Oil Price-Macroeconomy Relationship", Journal of Monetary Economics, 38(2), 215-220.

Lee, K. \& S. Ni \& R.A. Ratti (1995), "Oil Shocks and the Macroeconomy: The Role of Price Variability”, The Energy Journal, 16(4), 39-56.

Mork, K.A. (1989), "Oil and the Macroeconomy When Prices Go Up and Down: An Extension of Hamilton's Results”, Journal of Political Economy, 97(3), 740-744.

Raymond, J.E. \& R.W. Rich (1997), "Oil and the Macroeconomy: A Markov State-Switching Approach", Journal of Money, Credit and Banking, 29(2), 193-213. 